\title{
BIOGENIC SPELEOTHEMS: AN OVERVIEW ${ }^{1}$
}

\author{
Paolo FORTI 2
}

\begin{abstract}
The idea that speleothems may be somehow influenced by living organisms is rather old, but specific studies have only started in the last few decades and presently there are only a couple of systematic paper on this topic. The role of micro-organisms is perhaps the best investigated even if it is not fully understood, while studies over upper organisms and speleothems in a cavern environment are scarce and details are not always given on the involved genetic mechanisms.

The aim of the present paper is to give an updated overview on these topics in order to enhance the interest of the scientific community. In fact the complex biochemical reactions involved in the development of the different cave deposits, though still not well understood, clearly have an interest and an importance far exceeding the simple speleogenetic interest.
\end{abstract}

Keywords: Chemical deposits in caves, micro-organisms, plants, upper animals

\section{RIASSUNTO}

L'idea che la formazione di depositi chimici secondari in grotta possa essere in qualche modo influenzata da organismi viventi è abbastanza antica, ma solo da poche diecine di anni sono partiti studi specifici sull'argomento e a tutt'oggi esistono solamente un paio di lavori generali in questo campo.

Il ruolo giocato dai microrganismi è sicuramente quello meglio studiato anche se si è ancora ben lungi dall'averlo definito in maniera puntuale; al contrario il ruolo giocato dagli organismi superiori nell'evoluzione dei depositi chimici secondari di grotta è ancora molto poco investigato e nei pochi lavori presenti in bibliografia raramente vengono forniti dettagli sui meccanismi genetici.

Lo scopo del presente lavoro è quello di dare una panoramica aggiornata su questi argomenti anche allo scopo di aumentare l'interesse della comunità scientifica su questi temi. In fatti le complesse reazioni biochimiche che controllano l'evoluzione dei differenti speleotemi, la maggior parte delle quali sono ancora del tutto non studiate, hanno certamente un interesse e un'importanza che travalica di gran lungo il semplice studi speleogenetico.

Parole chiave: Depositi chimici in grotta, miroorganismi, piante, animali superiori

1 Invited talk at the *** Int. Symp of Biospeleology, Interlagos, Brasil

2 Istituto Italiano di Speleologia, Via Zamboni 67, 40127 Bologna, Italy. E-mail: forti geomin.unibo.it 


\section{I - Introduction}

The idea that the development of the secondary chemical deposits in caves may be somehow influenced by living organisms is rather old (SHAW, 1997): the shape and the internal structure of some speleothems (stalactites, stalagmites, coralloids...) suggested to the early visitors of caves the possibility that they grow as plants even though the current idea was that minerals (and therefore also the speleothems) were living organisms but at a lower level with respect to plants or animals until the second half of XVII century.

In the second half of the XVII century a scientist put forth the idea that speleothems are true "rock plants" (BEAUMONT, 1676), the development of which is very similar to that of the normal trees.

The theory was later perfected in 1704 by J. P. TOURNEFORD who wrote:

“...That certain rocks nourish themselves in the same way as plants. Perhaps they reproduce also in the same way.... that there are seeds which gradually swell up and develop the regular structure which is perhaps hidden beneath their surface... Thus the congelations grow up from seeds."

These are the reasons why in the XVIII century some of the most common types of speleothems were often represented just as part of a tree: with stalactites as roots, stalagmites and columns as trunk, helictites as leaves or flowers (Fig. 1).

Since the second part of XVIII century the progress in chemical studies allowed the detection of the main mechanisms by which calcite and other minerals deposit in caves and consequently any possible biogenic interaction in speleothem evolution was rejected for over one century.

Fig. I - The speleothems of the Antiparos cave (Greece) represented as living plants in an engraving of the XVIII century

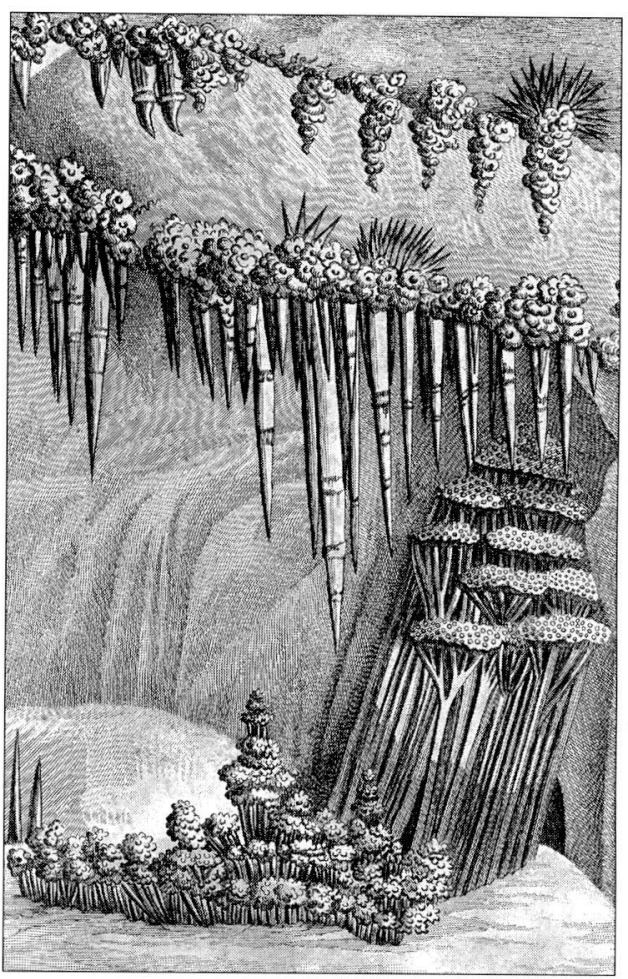


But the increase of scientific observation inside caves which characterised the XX century allowed the opportunity to reconsider all the matter and therefore in the last 50 years the possibility that living organisms (mainly microorganisms) may somehow control the development of chemical deposits in caves was once again taken into consideration.

Today the fact that living organisms may influence, and in reality often control the external shape and/or the chemical composition of the speleothems is generally accepted. Nevertheless systematic studies on this topic have never been done, except for a few dealing with microbiology (SASOWSKY \& PALMER, 1994; NORTHUP et Al., 1997).

Research in this specific field started only fifty years ago, but their development progressively enhanced the role played by micro-organisms in the genesis and the evolution of secondary cave minerals. Therefore at present someone even doubts that caves may host speleothems developed without the active and/or passive control by living organisms.

The role of micro-organisms is perhaps the best investigated, at least for some of the most important reactions, even if it is far from being fully understood. Studies over upper organisms and spelothems in caves are scarce and normally refer only on the occurrence of biologically controlled chemical deposits saying nothing on the involved genetic mechanisms.

The aim of the present paper is to give an updated overview on these topics in order to enhance the interest of the scientific community in the study of the biogenic speleothems.

\section{II - The role of micro-organisms}

Presently, it is well established that microorganinsms can directly cause biomineralization through enzymes, or they can produce substances that lead to the precipitation of minerals (e.g. by changing the $\mathrm{pH}$ in their surrounding) or they may become the privileged support to nucleation.

The microbial processes in caves often involves redox reactions. The microbial players are varied: aerobic (chemiolithotrophs) microorganisms, which obtain energy directly from the oxidation of inorganic compound, but also anaerobic (heterotrophs) organisms which obtain energy from the oxidation of organic matter and reduce inorganic compounds. Best examples of such processes are given by the "sulfur cycle", where both sulfur-oxidizing and sulfate reducing bacteria are involved (fig. 2). 


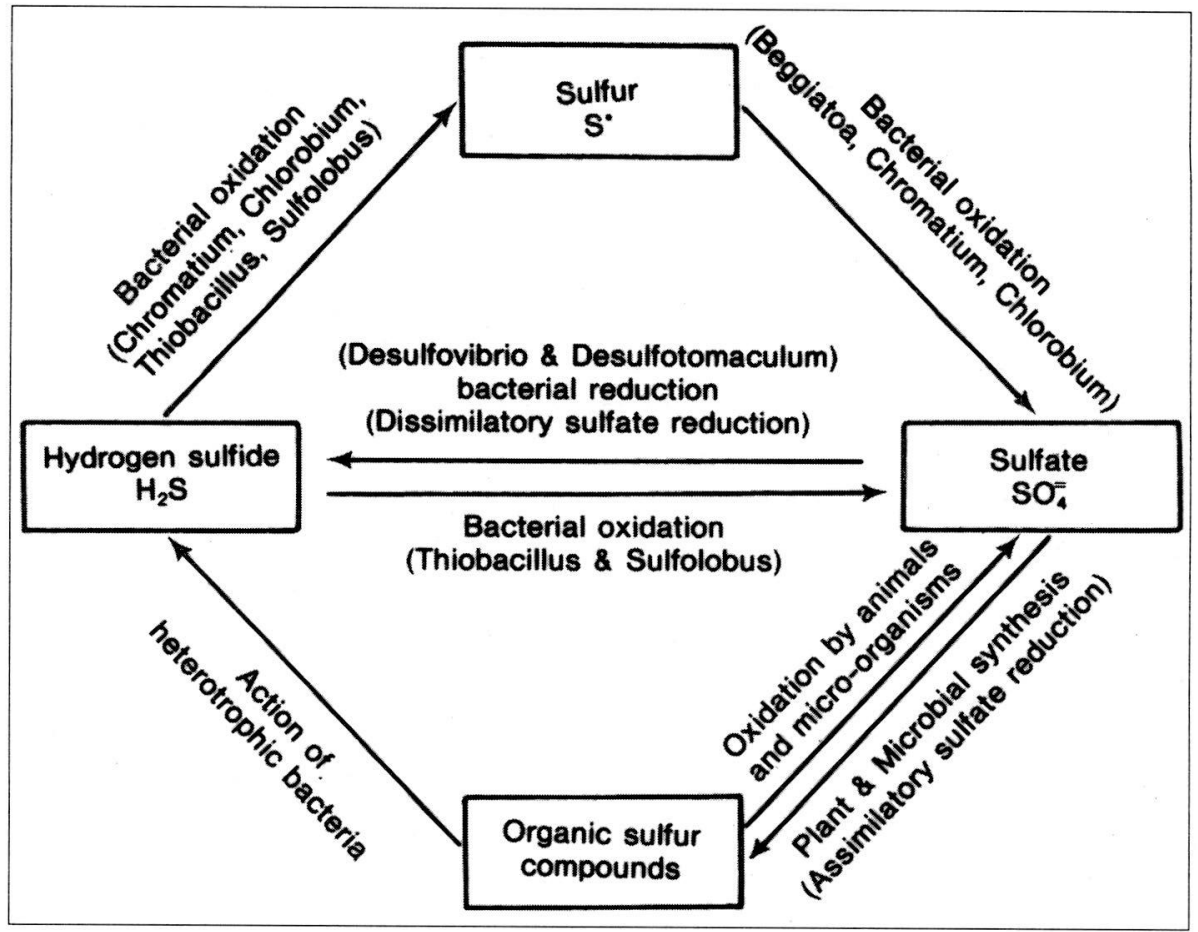

Fig. 2 - The sulfur cycle and the main micro-organisms involved in it

\section{1 - The "sulfur cycle"}

The microbial reactions of the "sulfur cycle" are perhaps the best studied and have been proved to cause the development of a lot of cave minerals: native sulphur, gypsum and iron oxides-hydroxides are the most common speleothems developed by them, but plenty of others (Tab. 1) have been reported in literature (HILL \& FORTI 1997; FORTI 1989, 1996).

Sometimes the large amount of organic matter produced in the "sulfur cycle" allows for the evolution of speleothems (pseudo-stalactites) consisting of single organic mat (mucus), which are normally called "mucolites" (Fig. 3).

Apart those related to the "sulfur cycle", many other kinds of biomineralization can occur in the cave environment: the most important of which are:

- The Salpeter evolution

- The Phosphate deposition

- The Guano digestion 
Tabl. 1-Minerals directly related to Sulphur Cycle

\begin{tabular}{|c|c|c|c|}
\hline & & Minerals & Genetic mechanisms \\
\hline 1 & Sulphur & & $\begin{array}{l}\text { anaerobic reduction of sul phates } \\
\text { aerobic oxidation of sulphides }\end{array}$ \\
\hline 2 & Gypsum & & $\begin{array}{l}\text { direct reaction of } \mathrm{H} 2 \mathrm{SO} 4 \\
\text { over limestone or dolostone }\end{array}$ \\
\hline 3 & Calcite & & $\begin{array}{l}\text { incongruent dissolution of } \\
\text { sulphates }\end{array}$ \\
\hline 4 & $\begin{array}{c}\text { Fe-Mn } \\
\text { oxyhydroxides }\end{array}$ & $\begin{array}{l}\text { Goethite, Hematite, Magnetite, } \\
\text { Lepidocrocite Braunite, Pyrolusite, } \\
\text { Romanechite, Hausmannite... }\end{array}$ & $\begin{array}{l}\text { final products of the sulphide } \\
\text { oxidation }\end{array}$ \\
\hline 5 & $\begin{array}{l}\text { Metallic } \\
\text { Sulphates }\end{array}$ & $\begin{array}{l}\text { Barite, Anglesite, Brochantite, } \\
\text { Fibroferrite, Jarosite, Halotrichite } \\
\text { Melanterite, Rozenite, Zaherite... }\end{array}$ & $\begin{array}{l}\text { final products of the suphide } \\
\text { oxidation in presence of } \\
\text { metallic ions }\end{array}$ \\
\hline 6 & $\begin{array}{c}\text { Metallic } \\
\text { Carbonates }\end{array}$ & $\begin{array}{l}\text { Siderite, Auricalcite, Azurite, } \\
\text { Malachite, Cerussite, Rosasite, } \\
\text { Hydrozincite... }\end{array}$ & $\begin{array}{l}\text { final products of the sulphide } \\
\text { oxidation or of the mobilization } \\
\text { of sulphates in carbonate environment }\end{array}$ \\
\hline 7 & $\begin{array}{c}\text { Metallic } \\
\text { Phosphates }\end{array}$ & $\begin{array}{l}\text { Hopeite, Parahopeite, Tarbuttite, } \\
\text { Scholzite, Tinticite, Sampleite... }\end{array}$ & $\begin{array}{l}\text { final products of the sulphide oxidation } \\
\text { in presence of guano and/or bones }\end{array}$ \\
\hline 8 & Opal & & $\begin{array}{l}\text { deposition induced by } \mathrm{pH} \text { lowering } \\
\text { during the sulphide oxidation }\end{array}$ \\
\hline 9 & Sulphides & Pyrite, Marcasite.... & anaerobic reduction of sulphates \\
\hline 10 & Silicates & Allophane, Endellite... & $\begin{array}{l}\text { deposition in strongly acidic } \\
\text { environment induced by sulphide } \\
\text { oxidation }\end{array}$ \\
\hline
\end{tabular}

Fig. 3 - A mucolite in the sulfide rich part of the Frasassi Karst System (Italy)

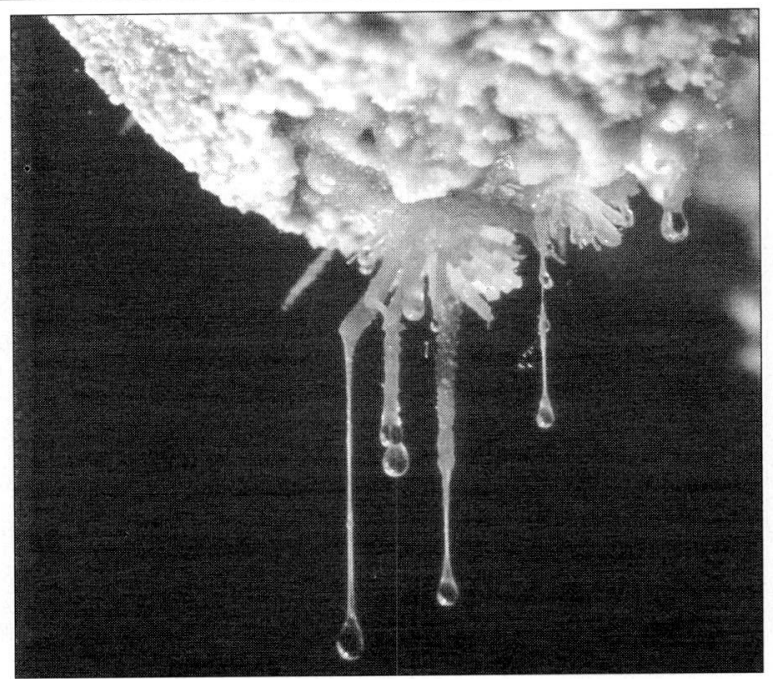




\section{2-The salpeter evolution}

Actually it is well known that the deposition of saltpeter (nitrocalcite) and all the other cave nitrates, is driven by nitrifying bacteria, but in the early times of cave science, there were several supposed origins for nitrates in caves. Among them the most curious referred to the uplifting of nitric gas from deep inside the earth (ZIMMERMANN, 1789), or postulated the deposition by electric currents (GIOVENE, 1819). Only in 1839 the Danish Lund put forth the hypothesis that:

“...Salpeter earth (in caves) derives from surface organic matter...”

Anyway this theory took over 150 years to be demonstrated: in fact only in $1981 \mathrm{C}$. HILL established that:

“... nitrates leached from the surface soils, transported into caves by seeping waters, are deposited by the aid of the nitrogen bacteria Nitrobacter..."

Moreover it is presently proved that the same mechanism may also leach nitrates from guano, rat droppings, urine and deposit them into cave earth.

Therefore it is only in very peculiar cave environments (like the volcanic caves) that salpeter may have a inorganic origin related to weathering of basaltic rock (HILL \& ELLER, 1977).

\section{3-The phosphate deposition}

The sources for $\mathrm{PO}_{4}^{-3}$ ions to produce minerals in caves are normally represented by bones and/or guano deposits inside the cave.

The reaction between phosphoric acid cave walls, clay and sand in the floor and/or other minerals dispersed in the hosting rock is absolutely an inorganic process, but the transformation of organic phosphorous into $\mathrm{PO}_{4}{ }^{-3}$ ions seems to be always, or at least often, driven by the micro-organisms ruling the complex mineralization (mainly oxidation) processes of the organic mat inside a cave.

Therefore probably almost all of the known cave phosphates are at least partially biogenic products.

Anyway no specific study on this topic has been done until now. 


\section{4-The guano digestion}

Mineralization of guano is a complex mix of different reactions, many of which are surely biologically driven. The previously described, related to the sulphur cycle, the saltpeter and phosphate evolution are among them and surely the most important: all of them occurring inside guano deposits.

Anyway micro-organisms may reasonably control many other processes, like those causing the deposition of

- Halite

- Gypsum

- Iron and manganese oxides-hydroxides

Until present no specific study on the eventual biologically driven guano reactions has been done. Anyway recently, in a different context (without guano) it was possible to demonstrate that the iron oxides-hydroxides depositing inside Odyssey Cave, Bugonia, Australia are surely a biogenic mineralization: here the bacteria Lepothrics spp and Gallionella sp were prooved to precipitate ferrihydrite with characteristic morphologies (CONTOS 2001, CONTOS et Al. 2001).

\section{5-Biogenic speleothems in silica-Rich cave environments}

The presence of high silica content in the cave wall and/or sediments may allow the development of peculiar micro-organisms which may in turn give rise to biogenic mineralizations.

In some volcanic caves of Japan (KASHIMA et Al., 1989) the development of several silica coralloids and helictites have been found to be strictly related to the presence of colonies of diatoms (genus Melosira). In fact these speleothems consist mainly of skeletons of such organisms that are cemented by a few of silica. Their presence is strictly confined in the first part of the caves where a little of the external light can still reach the colonies of Melosira, because they need the energy supplied by the light to live. The light control is evident non only by the fact that these speleothems develop only in the threshold zone but also by their shape, which is always pointing towards the cave entrance.

Beside this proven occurrence of biologically controlled speleothems in silica rich cave environment, there are several other cases in which a biogenic origin seems to be highly probable. 
Filamentous organic structures have been reported in opal coralloids from quartzite caves in Venezuela (URBANI 1996, ONAC et Al. 2001) and in opal-sulphur speleothems in a gypsum cave of Sicily (Forti \& Rossi, 1987) (Fig. 4).

Moreover in many of the lava tubes of the Pico Island (Azores) weathering of basaltic rock caused the evolution of a widespread amorphous silica moonmilk (Fig.5), extremely rich in organic matter (over 20\%, unpublished data by the author), thus suggesting that the weathering process is probably driven by micro-organisms. In the same island there are gigantic opal floswstones (up to 5-6 meter long and over $1 \mathrm{~m}$ thick) inside the Argar do Carbalo volcanic cave, which seem to derive from the diagenesis of the previously described silica moonmilk and, therefore, should be considered biogenic speleothems.

Fig.4 - Santa Ninfa gypsum cave (Sicily): an opal-sulphur flowstone developed due to the biological oxidizing reaction of the sulphur cycle.

Fig. 5- Amorphous silica moonmilk from a lava tube of the Pico island (Açores): the speleothem is very rich in organic matter thus suggesting some biogenic mechanisms active in its evolution.

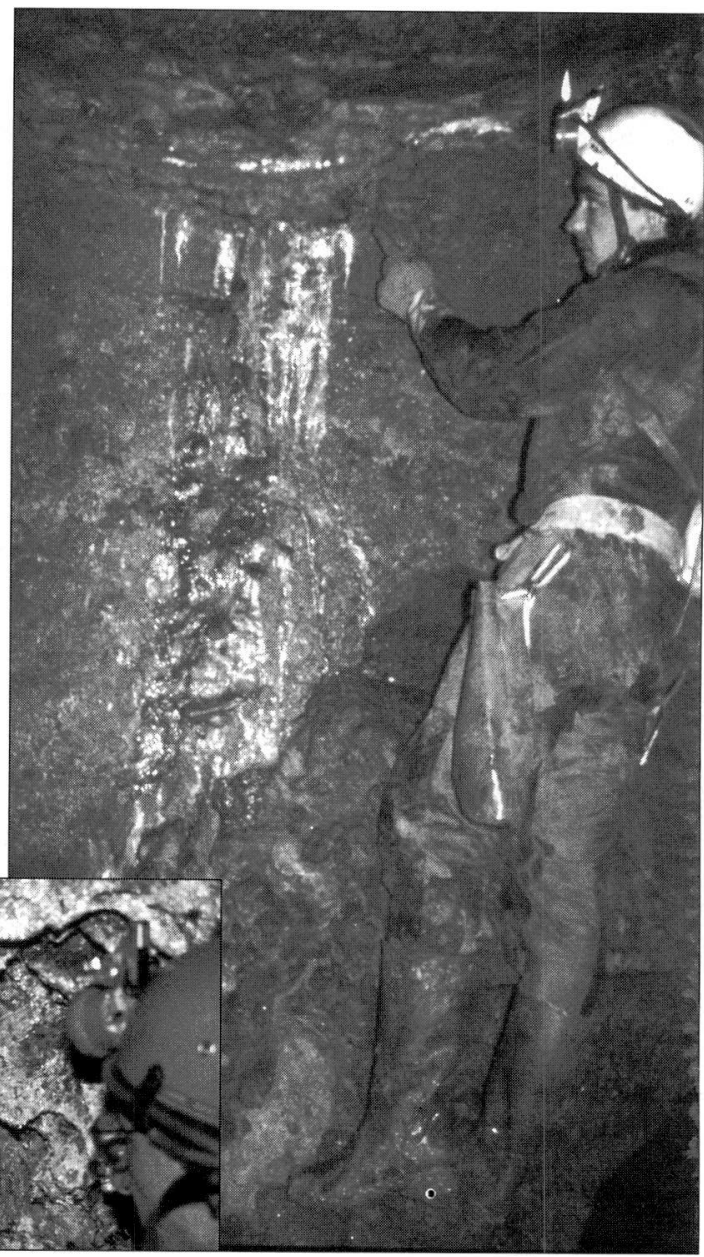




\section{6-Biogenic Carbonate Speleothems}

It is presently well accepted that by far the large majority of carbonate speleothems developing in a cave environment are absolutely inorganic, anyway at least some of these deposits undergo biological control.

Fungi, Algae and bacteria have all been implicated in the precipitation of carbonate dripstones but until recently it was not proved if these micro-organisms helped actively (by driving the chemical process) or passively (serving as crystallization nucleus) in the deposition, or if they where just accidentally buried there, which seems to be the rather more common occurrence.

Perhaps the best example of these processes are represented by the gigantic stromatolitic stalactites developing worldwide just at the entrance of many caves mainly in the tropical area. The algae colonies responsible for their development needs strong light to survive and therefore such formations are present only up to the threshold zone.

Over a score of several tens of years, a extensive documentation of the microbial precipitation of calcium carbonate exists in non cave carbonate/travertine literature (EHRLICH 1996), their direct involvement in cave carbonate deposition have only been demonstrated very recently (CONTOS et Al. 2001a,b; CONTOS 2001). In her experiments CONTOS proved the active role played by bacteria in precipitating calcite crystals, and also experimentally evidenced that micro-organisms in Nullarbor caves (Australia) control also the shape of the generated calcite crystals, which are far different from those of the inorganic precipitated ones.

Fungal hyphae may act as nuclei for crystallization and a site for attachment for crystals. Algae can trigger the precipitation of calcium carbonate from solution, and may subsequently trap and bind the particles to carbonate speleothems. This may occur as the algae change the microclimate by respiring carbon dioxide and consequently causing the $\mathrm{CaCO}_{3}$ to precipitate. Anyway due to their photosynthetic nature, except in show-cave environments, algae will only contribute to carbonate deposition at the entrance and twilight region of the caves, being responsible for the evolution of the well known stromatolithic stalactites, which may sometimes reach even gigantic dimension in the tropical areas. Finally bacteria which utilize carbon dioxide (like Thothrix in the sulphur cycle) have been proved to cause accelerated carbonate speleothem growth.

Among carbonate speleothem types, moonmilk is that which most frequently seems to be originated through microbiological reactions. In fact the two most common mechanisms for the evolution of moonmilk (HILL \& FORTI, 1997) are:

1 - Biochemical corrosion of the bedrock by organic acid produced by microorganisms (Arthrobacter, Flavobacterium, Pseudomonas) 


\section{2 - Active precipitation of moonmilk by bacteria (Macromonas Bipunctata)}

Finally it is important to note that mocroorganisms should be fundamental also in the deposition of moonmilk made by different minerals: not only in the case of the amorphous silica already cited, but also when the moonmilk is made by gypsum, amorphous silica, etc. (FORTI, 2000) even if no specific studies have been done on this topic at present.

\section{III - The role of plants and animals in the evolution of speleothems}

If the actual knowledge on the role played by microorganisms in speleothem evolution are surely not exhaustive but fairly good, the situation is completely different when considering the effect of plants and animals over the secondary chemical deposits in caves. In fact, in these two fields the research is extremely scarce and the available few papers always deal with spot observations without any attempt to consider the topic from a general point of view.

Presently it's well accepted and enogh documented througout the world that plants (mainly roots) and remnants of animals (spider nets, bones etc...) may passively improve the development of speleothems by enhancing capillary migration of waters to places where evaporation may occur.

Anyway, in most cases, an active involvement of plants and animals in the evolution of speleothems is still speculative.

\section{1-The influence of roots on speleothem growth}

The roots apparatus is the single portion of a tree which may somehow interact with speleothem evolution.

The interaction may affect both the morphology of the speleothem (passive effect) and its chemical composition (active effect).

Anyway, plants cannot normally directly control the mechanisms of chemical deposition deep into the caves, because they need light to survive and their roots can hardly reach depths of several tens of meter. On the contrary in the show caves, where light is artificially supplied, plants often become not only a element of disfigurement but also they may lead to a halt in the calcium carbonate deposition or even cause the corrosion of speleothems, due to the acid secretion of their roots.

A peculiar lithogenetic (active) effect induced by plants was described in the gypsum area of Bologna (FORTI,1983): with the life activity of plants causing a concentrated local increase of $\mathrm{CO}_{2}$ close to the roots apparatus that allows the development of the incongruent dissolution of gypsum (Fig. 6) which leads to the evolution of car- 
bonate speleothems to form layers inside gypsum flowers or even thin, pure calcite, flowstones (Fig. 7).

The morphological (passive) effects induced by roots over spleothems are much more frequent and evident: in fact when roots enter cave voids their surface may become a preferential area for the flow of the seeping water and, if the suitable environmental conditions (diffusion of $\mathrm{CO}_{2}$ but also evaporation) exist, for calcium carbonate deposition. This mechanism causes the evolution of peculiar stalactites and columns, with a tilted often anastomized shape, over which several pseudo-helictites

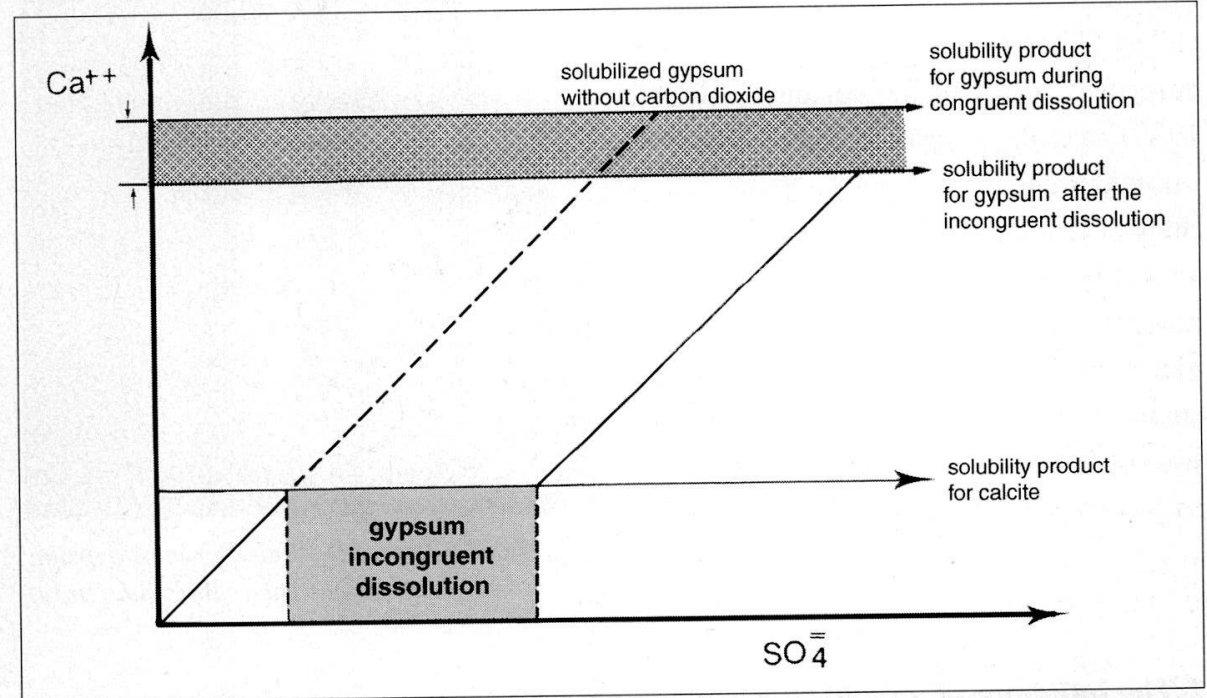

Fig. 6 - The incongruent dissolution of gypsum: when a $\mathrm{CO}_{2}$ rich water flows over gypsum the saturation point with respect to $\mathrm{CaCO}_{3}$ is reached quicker thus the deposition of calcite causes an additional solubilization gypsum.

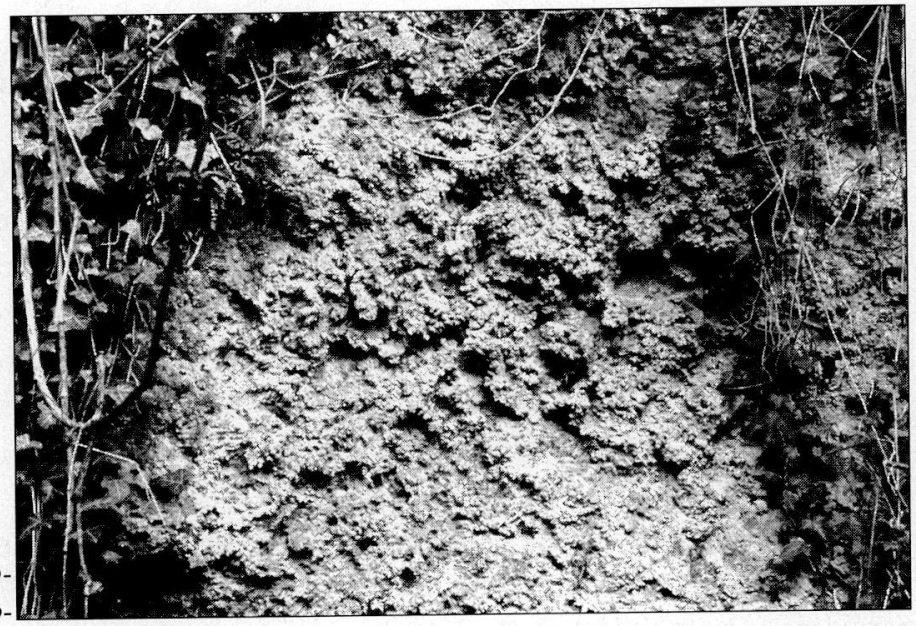

Fig. 7- Calcite-gypsum flowers over gypsum rock near Bologna (Italy): the deposition of calcite is caused by the localized increase of $\mathrm{CO}_{2}$ close to the roots. 
grow (Fig. 8): these speleothems, growing over roots, have been observed with the same characteristics all over the world and are normally called "rootsicles" (HILL \& FORTI 1997).

Finally, in the wet tropical environment, the root apparatus of large trees may become the main driving factor for the evolution of those peculiar speleothem, called "Showerhead", which were firstly described inside Brazilian caves (LINO, 1989) and then observed in many other tropical areas.

Showerheads are cone-shaped, stalactitic speleothems from which a steady or intermittent shower of water can emerge: in many cases they develop along large fissures widened by the presence of roots which in turns are partially or totally transformed into rootsicles.

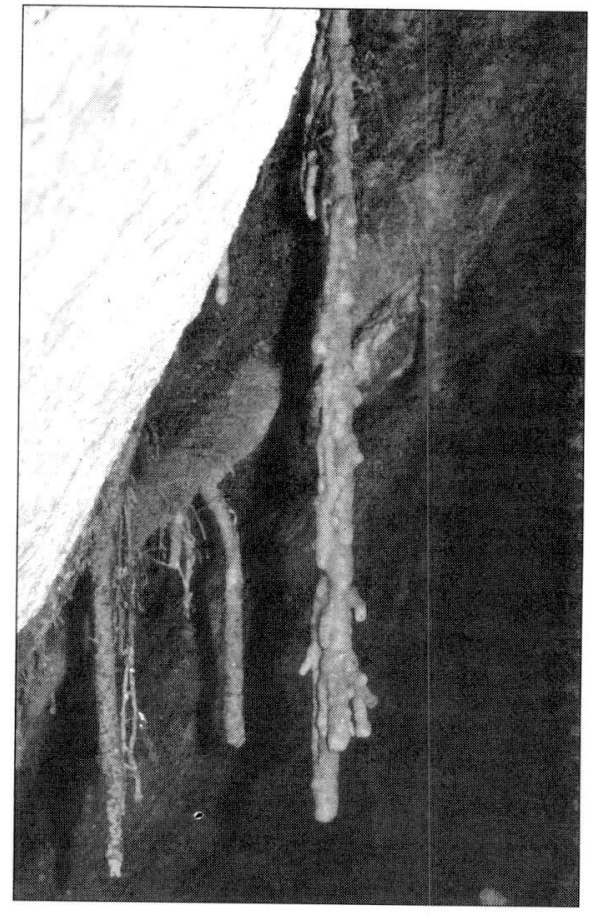

Fig. 8-Calcite rootsicles from a gypsum cave near Bologna (Italy)

\section{2-The influence of animals on spleleothem growth}

When considering the influence of animals on the chemical cave deposits, it must be clear that lithogenetic phenomena like corals or others biogenic structures growing inside sea caves cannot be considered speleothems, because a cavern environment is normally not fundamental for their genesis and/or evolution. Therefore on the basis of the existing literature it should be stated that the influence of animals over speleothems is extremely scarce.

In reality it is highly probable that even upper living organisms should be able to influence specific speleothems inside peculiar cave environments, therefore the lack of papers on this topic would be the consequence of the scarcity of specific observations instead of the rarity of the event.

Most of the existing papers deals with marine caves in which the biogenic calcite overgrowth on pre-existing continental (inorganic) speleothems (Fig. 9) is induced by serpulids (ANTONIOLI et Al., 2001). 
Anyway this kind of overgrowth rarely gives rise to specific new speleothems, normally just enlarging the pre-existing speleothem, the morhology of which results reasonably unaffected.

Sometimes, if the environmental conditions are suitable, the biogenic deposition induced by sepulids may allow for the development of single biogenic formations, the most characteristic of which are presently the "biogenic trays" observed inside the Lu Lampiune cave in Apulia (ONORATO et Al., 2001).

The speleothems inside this cave consist of big (up to 2 meters long and $40 \mathrm{~cm}$ in diameter) clearly deflected stalactites: in fact their tip always points towards the dominant water flow inside the cave (Fig. 10): the resulting growth direction changes from subhorizontal close to the cave entrance to rather vertical in the cave bottom. The shape of these speleothems is not conical but flattened with the major axis being 3-4 time greater than the smaller one and with the tip larger than the base.

The analysis of the internal structure evidenced the absence of even a small pre-exist-

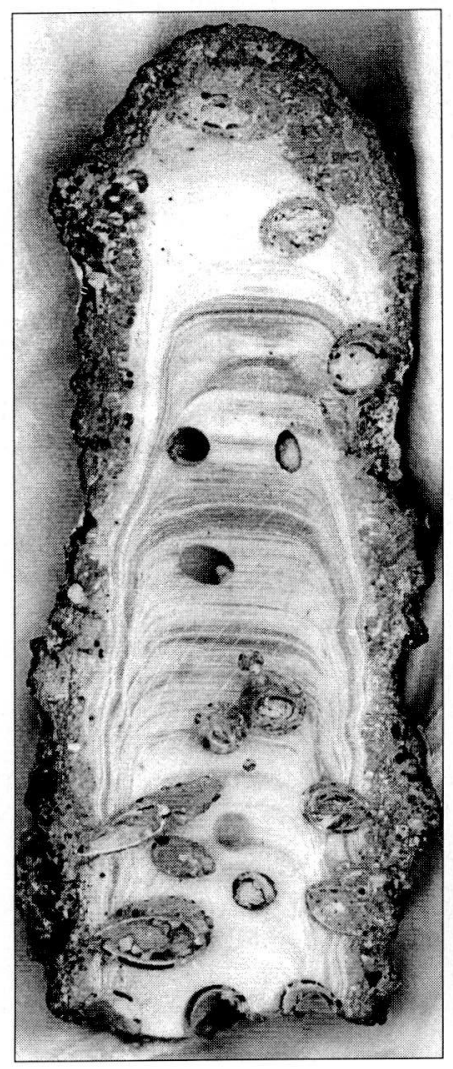

Fig. 9- Sepulids overgrowth on submerged stalactites (photo by Fabrizio Antonioli)

Fig. 10- The biogenic trays of Lu Lampiune cave, Apulia, Italy (photo Raffaele Onorato, C.S.S. Apogon)

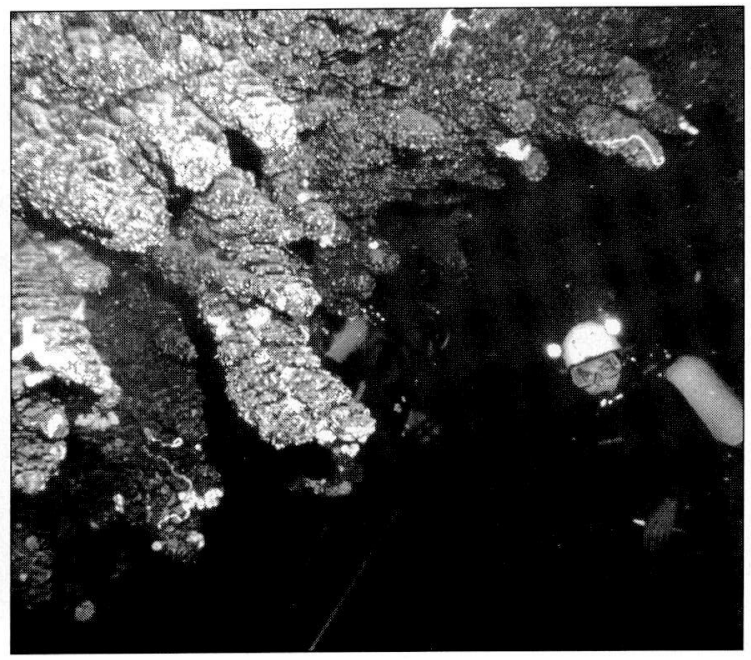


ing continental stalactite (Fig. 11), being totally developed due to a biogenic deposition in the marine environment.

Morphologically they are extremely similar to the gypsum trays described inside the caves of New Mexico (CALAFORRA \& FORTI, 1994). In both these occurrences the deposition is controlled by the same agent (they develop against the flow direction), the fluid being the only difference (water in the $\mathrm{Lu}$ Lampiune cave and air in the New Mexico caves) (Fig. 12). Practically the direction of evolution of these biogenic stalactites is controlled by the serpulids, which must filter the water to obtain the necessary

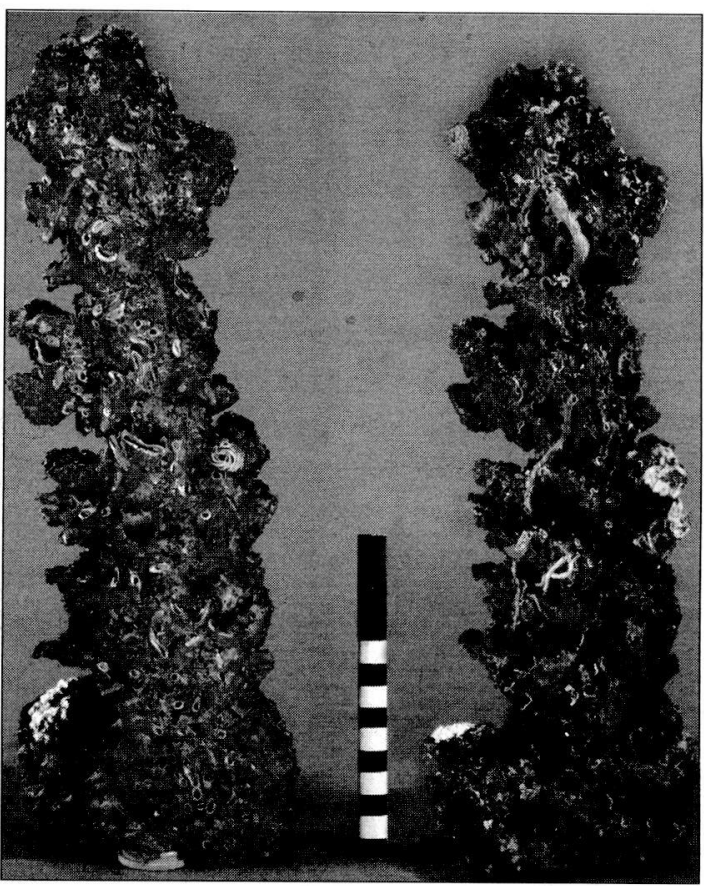

Fig. 11 - Longitudinal section of a trays from $\mathrm{Lu}$ Lampiune cave (left: internal part; right:external surface): all its structure is clearly biogenic

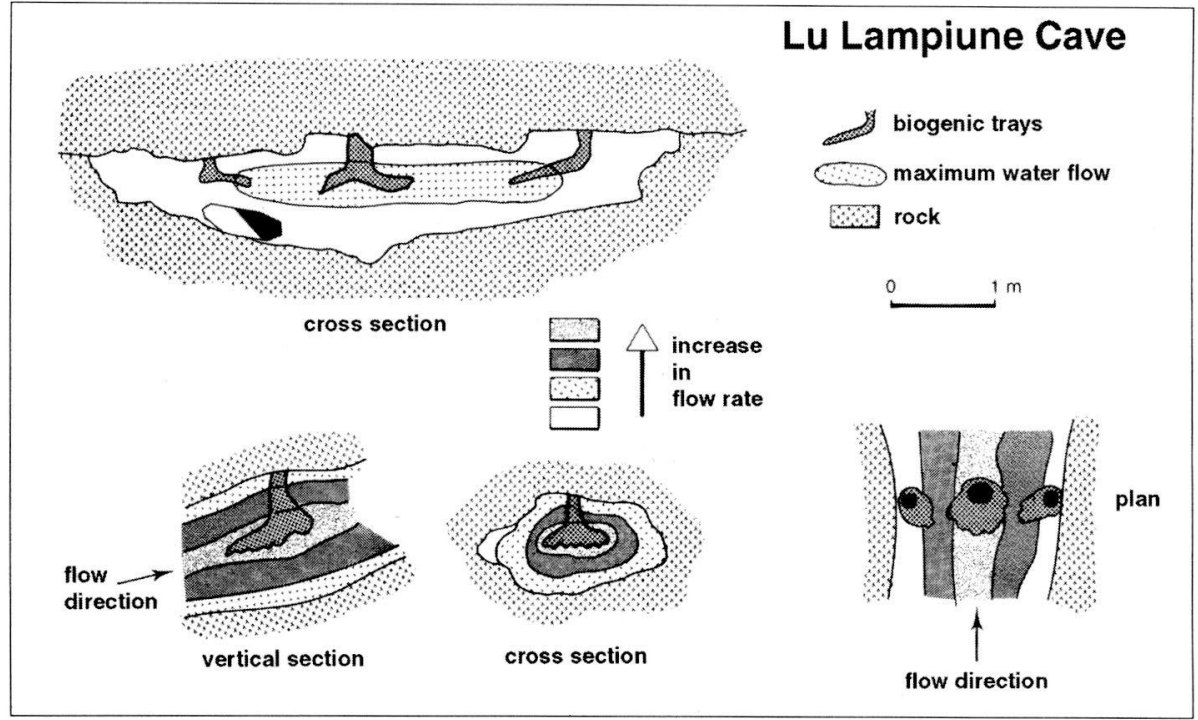

Fig. 12 - Schematic sections of Lu Lampiune cave where the water flow control over the shape and the direction of the biogenic trays is evident. 
trophic support, and therefore tend to direct just upstream the water flow. The apical part is flattened and enlarged with respect to the basal section of the stalactites for the same reason: in fact the trophic support is maximum at the apex rapidly decreasing toward the base, thus allowing the enlargement of the tip and avoiding the radial growth of the other part of the trays.

Until now a rather large single biogenic flowstone made by upper living organisms has been described from a continental karst system in the southern part of Italy (POLUZZI \& MINGUZZI, 1998).

The Vallone Cufalo gypsum cave (Verzino, Italy) is an active sinkhole with a river flowing inside. It hosts a rather large flowstone consisting of a gently terraced calcite crust up to $50 \mathrm{~cm}$ thick, $4-5 \mathrm{~m}$ wide and some tens of meters long, covering the cave floor along the subterranean stream (Fig. 13). Its complex genesis has been referred to the large community of larvae of a troglobic insect (Tricoptera Wormaldia), once living inside the cave over wide anthropogenic organic matter (olive oil factory waste discharged every year into the cave). Their life processes caused the production of large amounts of $\mathrm{CO}_{2}$ which in turn reacted with the water saturated in gypsum thus causing the deposition of calcite just around the worms. The final morphology of the flowstone was the result of a combined action of larvae living activities and kinetic energy of the flowing water: in fact until the larvae were alive the tubes were bended upstream to catch as much fresh water as possible (Fig. 14), but

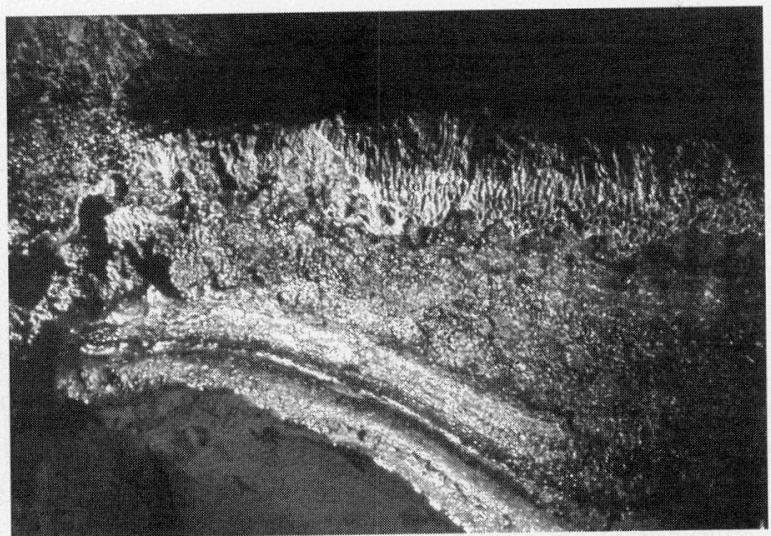

Fig. 13 - The biogenic flowstone of the Vallone Cufalo gypsum cave (Calabria, Italy).

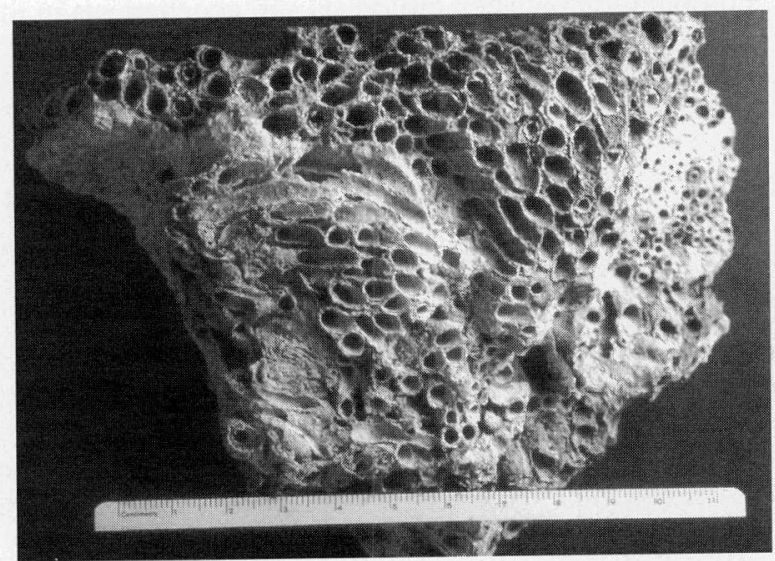

Fig. 14 - A close-up view of the biogenic structure of the flowstone of fig. 13: all the tubes are bended upstream thus allowing the larvae to receive fresh water. 
after their death \&/or evolution the further deposition of $\mathrm{CaCO}_{3}$ was controlled by the kinetic energy of the water transforming the upper part in a normal flowstone evolving downstream.

It is hard to believe that the Vallone Cufalo would be the only cave in the world in which the environmental conditions are suitable for an active upper living organism control over speleothems, therefore it seems reasonable that chemical deposits should develop due to the presence of animals in many other caves.

\section{IV - Final Remarks}

This short, and surely not exhaustive, overview on the biotic influence over the genesis and the evolution of spleothems clearly put in evidence the very important role played by living organisms, mainly micro-organisms, over the lithogenetic cave processes (speleothems and cave minerals evolution). The complex biochemical reactions involved in the development of the different deposits, though still not completely understood, clearly have a more interest and importance far exceeding the simple speleogenetic interest.

Normally they are low-enthalpy reactions and their knowledge is fundamental to improve our understanding of the natural mechanisms by which even orebodies of economic interest are formed and then mobilized. But the study of biologically driven speleothems is also fundamental to enhance the knowledge over peculiar environments like the chemioautotrophic ones, which are presently not well known despite their scientific interest. It is therefore reasonable to expect an increase in the co-operation between biologists and geochemists in the near future in order to obtain a fast improvement in the study of these phenomena.

In conclusion it can now be stated that:

Speleothems definitely does not develop via vegetative growth... But without biogenic control caves should be very poorly decorated!!!

\section{BIBLIOGRAPHY}

ANTONIOLI F., SILENZI S., FRISIA S. - 2001 - Tyrrhenian holocene palaeoclimate trends from spelean serpulids Quaternary Science Reviews. 20/15, 1661-1670

BEAUMONT J. - 1676 - Two letters concerning rockplants and their growth. Philos. Trans. Royal Soc. 11 (129), p.732-742 
CALAFORRA J. M., FORTI P. - 1994 - Two new types of gypsum speleothems from New Mexico: Gypsum trays and Gypsum dust. NSS Bulletin 56, p.32-37

CONTOS A. - 2001 - Biomineralisation in Caves PhD Thesis, University of Sidney 221 pp

CONTOS A., JAMES J.M., STONE D. - 2000 - Palaeoclimatic information from biominerals in Odyssey cave, Bugonia. Helictite 37(1) in press

CONTOS A.K., JAMES J.M., HEYWOOD B.R., PITT K., ROGERS P.A.W. - 2001Morphoanalyses of bacterially precipitated subacqueous calcium carbonate from Weebubbie Cave, Australia. Geomicrobiology J. 8(3), p.331-343

EHRLICH - 1996 - Geomicrobiology. M. Dekker Ed., New York, 716 pp

FORTI P. - 1983 - Un caso di biocarsismo nei gessi: le infiorescenze sopra i massi affioran ti Sottoterra 66: 21-25

FORTI P. - 1989 - The role of sulfide-sulfate reactions in speleogenesis X Int. Spel Congr., Budapest, v.1, p.71-73

FORTI P. - 1996 - Thermal Karst Systems. Acta Carsologica v.XXV, p.99-117

FORTI P. - 2000 - I depositi chimici presenti nella grotta Serafino Calindri. Sottoterra 110, p.31-41

FORTI P., ROSSI A. - 1987 - Le concrezioni poliminerali della Grotta di Santa Ninfa: un esempio evidente dell'influenza degli equilibri solfuri-solfati sulla minerogenesi carsica Atti e Mem. Com. Grotte "E.Boegan" n.26, 47-64

GIOVENE G.M. - 1819 - Del nitro e degli altri sali che l'accompagnano. Atti Ac. Soc. Sci. Modena, 18(2), p. 1-7

HILL C.A. - 1981- Origin of cave salpeter. NSS Bull. 43(4), p. 110-126

HILL C.A., Forti P. - 1997 - Cave minerals of the World, N.S.S. Huntsville, 464 pp.

HILL C.A., Eller P.G. - 1977 - Soda-niter in earth cracks of WupatkiNational Monument. NSS Bull. 39(4), 113-116

KASHIMA N., OGAWA T., HONG. S. H. - 1989 - Volcanogenic speleo-minerals in Cheju Island, Korea. J. Spel. Soc. Jap. V.14, p.32-39

LINO C. F. - 1989 - Cavernas: o fascinante Brazil subterraneo. Rios, Sao Paulo Ed., 280 pp.

LUND P.W. - 1839 - Extract from a letter on the fossil mammifera discovered by him in Brasil. Ann. Nat. Hist., London, 3(17), p.235-236

NORTHUP D. E., Reysenbach A. L., Pace N. R. - 1997 - Microorganisms and speleothems in Hill C.A., Forti P. - 1997 - "Cave Minerals of the World”, Nss., Huntsville, p.261266

ONAC B.P., VENI G., WHITE W.B. - 2001- Depositional environment for metatyuyamunite and related minerals from Caverns of Sonora. European J. of Mineralogy 24(1), p.135-143

ONORATO R., FORTI P., BELMONTE G., POTO M. - 2001- Grotta sottomarina di "Lu Lampiune": novità esplorative e prime indagini ecologiche Atti Convegno Castro in press 
POLUZZI A., MINGUZZI V. - 1998 - Un caso di biocostruzione in un ambiente di grotta. Mem. Ist. It. Spel. S. II, v. X, p.93-100

SASOWSKY I. D., PALMER M.V. - 1994 - Breakthroughs in Karst Geomicrobiology and Redox Geochemistry, Symposium Abstract, Karst Waters Institute, 112 pp.

SHAW T.R. - 1997 - Historical introduction in Hill C. \& Forti P. Cave Minerals of the world, N.S.S., p.28-43

TOURNEFORD J. P. - 1704 - Description du labyrinthe du Candie, avec quelques observa 406-424 tions sur l'accroissement et sur la génération des pierres. Mem.R.Acad. Paris, p.

URBANI F. - 1996 - Espeleotemas de ópalo de origen biogénico en cavidades desarrolladas en rocas silíceas. Bolivar y Apure (abs). $46^{\circ}$ Conv. Ann.Aso VAC, Barquisimento, Act. Cient. Venez. 47, supl 1.

ZIMMERMANN E.A. - 1788 - Voyage à la nitrière naturelle que se truove à Molfetta dans la terre de Bari en Apulia. Venezia, Storti, 44p 